\title{
Long-term mortality in patients with a prolonged postoperative intensive care unit (PICU) stay
}

\author{
M Guerrero Díez*, Á Callejo Martin, C Camús Sánchez, A Calderón, M Levstek, A Hermira Anchuelo, \\ M González Serrano, E López López
}

From ESICM LIVES 2015

Berlin, Germany. 3-7 October 2015

\section{Introduction}

Non-cardiac surgical patients undergoing major surgery are progressively older and with multiple associated comorbidity. A worse baseline status and complicated postoperative course is usually assumed in patients who die in the postoperative intensive care unit (PICU). This study evaluates mortality in patients with prolonged ICU stay and try to identify differences in subjects characteristics and to determine risk factors for mortality among those dying in ICU.

\section{Methods}

A total of 429 patients who underwent major surgery between January 2012 and December 2013, with an ICU stay of 2 days or more, were included in the study. We compared demographic characteristics (age, sex and ASA classification), type of surgery (emergent or not and reinterventions) and postoperative course variables (presence of vasoactive drugs, days of mechanical ventilation (MV) and immediate postoperative albumin and bilirrubin levels) between patients who died or not in PICU. Results were expressed as mean \pm SD for continuous variables or as a percentage of the group from which they derive for qualitative ones. A $t$-Student test was performed to assess whether the differences in means values of qualitative variables were statistically significant. Distribution of categorical variables was compared by Fisher's exact test. Odds ratios (OR) were

Table 1

\begin{tabular}{|c|c|c|c|c|c|c|}
\hline & & DEATHS & SURVIVALS & p-value & OR & $\mathrm{Cl}$ \\
\hline SEX & $\begin{array}{l}\text { Male } \\
\text { Female }\end{array}$ & $\begin{array}{l}27(54 \%) \\
23(46 \%)\end{array}$ & $\begin{array}{l}233(61,48 \%) \\
146(38,52 \%)\end{array}$ & 0,0722 & & \\
\hline AGE (mean \pm SD) & & $71,92 \pm 14,20$ & $67,04(15,46)$ & 0,0273 & 1,55 & $0,83-2,87$ \\
\hline$\overline{A S A}$ & $\begin{array}{l}\text { I } \\
\text { II } \\
\text { III } \\
\text { IV }\end{array}$ & $\begin{array}{c}0(0 \%) \\
10(20 \%) \\
30(60 \%) \\
10(20 \%)\end{array}$ & $\begin{array}{c}7(1,85 \%) \\
110(29,02 \%) \\
188(49,6 \%) \\
74(19,53 \%)\end{array}$ & 0,1826 & & \\
\hline EMERGENCY & $\begin{array}{l}\text { Yes } \\
\text { No }\end{array}$ & $\begin{array}{l}27(54 \%) \\
23(46 \%)\end{array}$ & $\begin{array}{l}203(53,56 \%) \\
176(46,44 \%)\end{array}$ & 0,1196 & & \\
\hline REINTERVENTION & $\begin{array}{l}\text { Yes } \\
\text { No }\end{array}$ & $\begin{array}{l}18(36 \%) \\
32(64 \%)\end{array}$ & $\begin{array}{l}117(39,87 \%) \\
262(69,13 \%)\end{array}$ & 0,0960 & & \\
\hline VASOACTIVE DRUGS & $\begin{array}{l}\text { Yes } \\
\text { No }\end{array}$ & $\begin{array}{c}43(86 \%) \\
7(14 \%)\end{array}$ & $\begin{array}{l}221(58,31 \%) \\
158(41,69 \%)\end{array}$ & $<0.01$ & 4,39 & $1,93-10,02$ \\
\hline DURATION of MV (mean \pm SD) & & $10,64(14,57)$ & $3,14(7,39)$ & $<0.01$ & 2,44 & $1,28-4,65$ \\
\hline ALBUMIN (mean \pm SD) & & $2,57(0,87)$ & $2,68(0,74)$ & 0,3967 & & \\
\hline BILIRUBIN (mean \pm SD) & & $1,09(0,90)$ & $1,15(1,23)$ & 0,6613 & & \\
\hline
\end{tabular}


calculated to identify risk factors for mortality. A p-value $<0.05$ was considered statistically significant for all the analysis.

\section{Results}

$50(11.65 \%)$ out of 429 patients died in our unit after staying 2 or more days. Statistically significant difference in age, use of vasoactive drugs and time of MV was observed between the 2 groups. In the univariate analysis, despite a wide confidence interval (CI), a 4 and 2.5 times increased risk of death was observed due to vasoactive drugs and prolonged mechanical ventilation, respectively. An increasing risk for advancing age was suggested but was not statistically significant. Results are summarized in Table 1.

\section{Conclusions}

Patients with a long stay who died in PICU were older and showed worse postoperative course. Use of vasoactive drugs and prolonged mechanical ventilation were identified as significant risk factors. Multivariate analysis should be performed to assess them as independent risk factors. Although these findings are consequent with literature, larger trials will be necessary to study more variables and estimate predictors of mortality in PICU.

Published: 1 October 2015

\section{References}

1. Characteristics and outcomes for critically ill patients with prolonged intensive care unit stays: In Crit Care Med Claudio M. Martin, Andrea D. Hill, Karen Burns, Liddy M. Chen 2005, 33:1922-1927.

2. Shukri F. Khuri, William G. Henderson, Ralph G. DePalma, et al:

Determinants of long-term survival after major surgery and the adverse effect of postoperative complications. Ann Surg 2005, 242:326-343.

doi:10.1186/2197-425X-3-S1-A740

Cite this article as: Guerrero Díez et al:: Long-term mortality in patients with a prolonged postoperative intensive care unit (PICU) stay. Intensive Care Medicine Experimental 2015 3(Suppl 1):A740.

\section{Submit your manuscript to a SpringerOpen ${ }^{\circ}$ journal and benefit from:}

- Convenient online submission

- Rigorous peer review

- Immediate publication on acceptance

- Open access: articles freely available online

- High visibility within the field

- Retaining the copyright to your article

Submit your next manuscript at $\boldsymbol{\Delta}$ springeropen.com 